\title{
The Strengths and Weaknesses of Languedoc-Roussillon SMEs Export
}

\section{Jalane $A^{*}$}

Paul Valery University-Montpellier III and University of Huelva, Huelva, Public University in Huelva, Spain

\begin{abstract}
The growing interest of various economies in increasing and promoting the participation of their SMEs in international trade requires a revival of research into the internationalization processes of companies, especially those of small and medium enterprises. The objective is to provide extensive year and overall theoretical overview of the processes of internationalization of SMEs in Languedoc-Roussillon and, by extension, of those of French companies. From an empirical standpoint, we will verify the factoring that determines the internationalization process followed by these SMEs, according to their organizational structure and intangible considerations, in order to highlight their similarities and differences to from the various theoretical approaches. We will also determine whether firms with a low rate of international export may improve their performance solely through the development and management of some factoring in the Born Globals (internal variables). The export rate associated with international activity makes sense for thesis organisms. In fact, it has become a necessary strategic option in order to offset the drop in demand in exporting countries. In addition, a major challenge is exporting given the stiff competition in international markets from competitors with huge resources and very different export behavior
\end{abstract}

Keywords: International new ventures; SMEs; Uppsala; Internationalization; Born global; Export achievement; International entrepreneurship; Export intensity

\section{Introduction}

The internationalization of companies is today a phenomenon to which we pay more attention to various fields. Linked to it is one of the leading players in the global economy: small and medium enterprise (SME). In fact, much of the literature has traditionally focused on large multinational corporations with subsidiaries in many countries, lending, except for rare occasions, less attention to small and medium enterprises. This requires a justification for this work which may, in addition complements other recent research on French SMEs.

This is why our main objective is to conduct a study of the internationalization of SMEs Languedoc-Roussillon process. For that, following this introduction, everything is structured in the following paragraphs. First, a theoretical synthesis is carried out on the phenomenon of internationalization of companies, focused on some fundamental aspects that have been following empirical contrast objects. Later, we explain the methodology used throughout the work. After outlining the main results obtained, we will conclude with some conclusions which are highlighted potential contributions of this study as well as some recommendations and avenues for future research.

\section{The Theoretical Approaches to Internationalization}

The pioneering work of the Uppsala Model are those of Wiedersheim and Jan-Paul [1] and Johanson and Jan-Erik [2], who consider that many companies are trading their international operations early in their growth, developing a gradual manner their external operations. Due to lack of knowledge of foreign markets, companies start by exporting to neighboring countries that are relatively similar and better known, while passing later by what is called the "settlement chain": 1) nonregular exports, 2) export through independent representatives or agents, 3) affiliate sales, and 4) production subsidiary. In each stage two important elements influence: psychic distance (integrated by differences in language, culture, political systems, level of education, level of industrial development, etc.) and the potential market size since the company may prefer to start operations in small markets where one requires less initial commitment of resources, where there is less competition.

The debate over the validity of the Uppsala Model has been the center of some later works in the northern countries. In one of these countries, Bent and Pedersen [3] indicate that the theoretical basis of the model (increased commitment as a result of accumulating knowledge) has not been called into question are for later research. In all cases, the accumulation of knowledge is complemented by views of other possible explanations for the progressive increase in the commitment i.e., exports growth, the need to accumulate sufficient financial resources and a formidable evolution competition.

During this, and the increasing proportion of significant businesses and in particular SMEs, very early in their lives, have a rapid international development, that is to say without going through a consolidation phase of their activities in a local environment, undermines the universality of the traditional model of internationalization in stages of Uppsala. These companies, called "Born Globals" or "International New Ventures" and that their creation dice tend to get a significant competitive advantage in the use of resources and the sale of products in several countries [4] are also defined as being of technological base are small businesses operating in international markets in the first days of their creation [5]. These are companies that through a series of elements grow in other markets in a dynamic way, where is less waiting time for learning and the accumulation of knowledge that can be applied to various productive activities and operations of the organization. For example, the literature emphasizes the fundamental role of the entrepreneur for rapid internationalization of new companies [4,6-

*Corresponding author: Jalane A, Paul Valery University-Montpellier III and University of Huelva, Huelva, Public University in Huelva, Spain, Tel: +34 95921 80 00; E-mail: aziz.jalane.s@gmail.com

Received August 30, 2015; Accepted September 21, 2015; Published September 28, 2015

Citation: Jalane A (2015) The Strengths and Weaknesses of Languedoc-Roussillon SMEs Export. Bus Eco J 6: 185. doi:10.4172/2151-6219.1000185

Copyright: @ 2015 Jalane A. This is an open-access article distributed under the terms of the Creative Commons Attribution License, which permits unrestricted use, distribution, and reproduction in any medium, provided the original author and source are credited. 
8]. Others mentioned the importance of relational capital of the founder or entrepreneur as a catalyst for the internationalization process [9]. Likewise, interconnections and personal corporate with public and private stakeholders are highlighted as a key element for access to new resources, impossible to obtain otherwise.

The increase in the number of companies that follow an accelerated internationalization process is mainly characterized by the development of five economic and social factors that encourage the creation of new businesses to international and global vocation from birth These factors are: existence of new market conditions, technological developments in the field of transport and communication, increased specialization of technical and business skills of local human resources, coordination actions and participation in international networks and the systematic elimination trade barriers.

Obviously, the competitive environment that exists is different from that which was in the early 70 s (when the Uppsala model was developed). Indeed, today the role of entrepreneurs is recognized in the literature as a determining factor in explaining the emergence of Born Globals [4,9], which are characterized to have an international mindset and having the majority of international experience that they acquired while working for multinationals in export departments or developing stockists abroad. Thus, in this group are people with a university education, multilingual and with an extensive network of international contacts. All these experiences and their knowledge to determine adequately the conditions in international markets in order to develop a fast and efficient entry.

Considering the premises of the Born Global approach, it is necessary to consider that the internationalization process is not influenced by a model based on geographical distance and cultural differences, it makes more sense to think of a model linked to networks, experience and knowledge of entrepreneurs acquired before the creation of the company.

Once described the characteristics and main differences between the Uppsala model and Born Global approach, it is necessary to identify a number of factors of a different nature that seem to influence the intensity of exporting companies, a influence differs depending on the type of internationalization adopted by the SMEs.

\section{Factors influencing the process of internationalization}

The internationalization processes followed by firms are influenced by the interaction of a number of factors, which can be grouped into three main groups: technological, structural and other intangible factors. Technological and structural factors as the work of Vernon, Dunning [9] and Cantwell [10], the elements of great importance in the internationalization of businesses. Studies of technological factors have generally been associated with the analysis of the actions of the companies in their efforts to develop $\mathrm{R}$ and $\mathrm{D}$, being the common point of research is to generate conclusions about the effect of these investments on the competitiveness of companies on foreign markets.

Regarding structural factors, one can distinguish a large number of variables that have been studied as crucial to the internationalization of companies. Calof $[11,12]$ studied the size of the company as a decisive factor; Vaupel $[13,14]$ examined the ownership of capital while Uppsala work studied the internationalization of view of firm age.

Compared to other intangible factors, studies on one aspect of intellectual capital indicate that the analysis and management of intangible nature elements is crucial to improve and optimize the competitiveness of enterprises, having a positive effect on the ability innovation and presence in certain markets [15]. In this regard, the study of the internal factors of the organization, such as human capital, which is defined as the set of skills, talents, skills, experience accumulated by an individual and which partly determine their ability to work or produce for itself or others; structural capital (intangible assets) as we wanted to define the body of knowledge that remains in the company at the end of the working day (including organizational routines, procedures, systems, cultures, etc.); and relational capital defined as the set of resources associated with external relations of the company with these customers, suppliers of goods, services or capital are essential to understand the main points of attention for effective development of business activities abroad. Complement in this group of internal factors of intangible nature, we must add other external to the company (externalities) as external demand, domestic demand, the level of competition on the domestic market, geographic location and trade agreements that make it easier and cheaper development of commercial activities outside, causing less uncertainty in target markets because in theory the rules are known and respected by all.

Similarly, other factors beyond the control of the companies are "psychic distance" and "geographical" between them and the client countries. That during these distances are just a fact being the export decision is taken based on information and knowledge available.

The three groups of factors just mentioned are mutually reinforcing to influence the process of internationalization of companies and affect their competitiveness. So, pay attention to the latter as a whole proves fundamental.

\section{Objectives and Methodology of the Research}

The geographical scope of our empirical research is the LanguedocRoussillon region. Two stages will be analyzing the internationalization of SMEs in the region, a descriptive analysis and econometric analysis.

Initially, a descriptive analysis we analyze SME exporters in the region, we based on the data from the survey carried out among these companies. The idea is to assess if they have the necessary elements to properly compete in other markets. The second stage will be a brief analysis econometric data obtained from sample data Born Globals companies say. The objective is to confirm the participation of certain structural factors as catalysts of SME internationalization process of Languedoc-Roussillon and compromise a significant amount of resources on international markets.

To set the object of study population, the first step was to detect the exporting SMEs (firms with less than 250 employees), whose seat is in the Languedoc-Roussillon region, companies that have some experience international marketing and exports represent a significant percentage of their turnover. Our claim was to conduct a structured e through a questionnaire survey, for which we needed a complete listing of these companies. However, the absence of such a document has forced us to develop indirectly. So, first, we made contact with various organizations that we believe could have this kind of data such as: Regional Chamber of Commerce and Industry (RCCI) and Directorate General of Customs and Indirect Taxes (DGDDI).

After developing a first directory, we have refined accordance with the objectives of this work, which gave as a result a population permanently configured by SMEs in 2004. We obtained the collaboration of 61 companies for a confidence interval of $95 \%$ with a maximum margin of error of $5 \%$. 


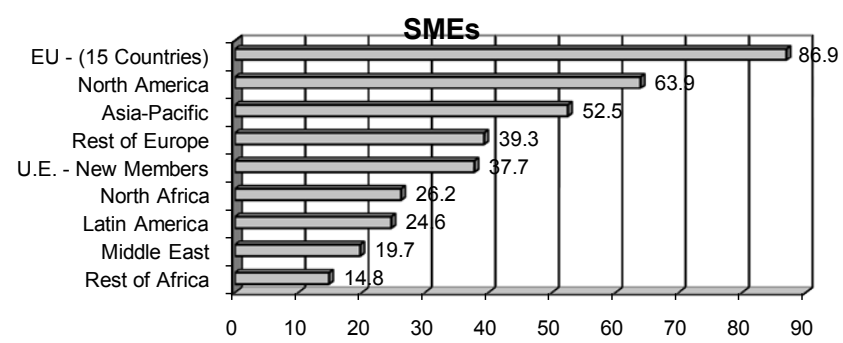

Source: own elaboration

Figure 1: Target markets Languedoc-Roussillon.

\begin{tabular}{|c|c|c|c|}
\hline Main activity & Frequency & Percentage & $\begin{array}{c}\text { Percentage } \\
\text { accumulated }\end{array}$ \\
\hline $\begin{array}{c}\text { Activities-games. Sports and } \\
\text { Cultural }\end{array}$ & 4 & 6.6 & 6.6 \\
\hline Wholesale & 16 & 26.2 & 32.8 \\
\hline Automobile Trade & 1 & 1.6 & 34.4 \\
\hline Manufacturing machines & 4 & 6.6 & 41.0 \\
\hline Agribusiness & $\mathbf{2 3}$ & $\mathbf{3 7 . 7}$ & $\mathbf{7 8 . 7}$ \\
\hline Chemical Industry & 2 & 3.3 & 82.0 \\
\hline Research and Development & 11 & 18.0 & 100.00 \\
\hline Total & $\mathbf{6 1}$ & $\mathbf{1 0 0 . 0}$ & \\
\hline
\end{tabular}

Source: Own elaboration

Table 1: Sectoral distribution companies

\begin{tabular}{|c|c|c|c|}
\hline $\begin{array}{c}\text { Total percentage of } \\
\text { exports }\end{array}$ & Frequency & Percentage & $\begin{array}{c}\text { Percentage } \\
\text { accumulated }\end{array}$ \\
\hline $\mathbf{0 - 1 0} \%$ & 15 & 24.6 & 24.6 \\
\hline $10-20 \%$ & 10 & 16.4 & 41.0 \\
\hline $20-30 \%$ & 7 & 11.5 & 52.5 \\
\hline $30-40 \%$ & 5 & 8.2 & 60.7 \\
\hline $40-50 \%$ & 2 & 3.3 & 63.9 \\
\hline $50-60 \%$ & 3 & 4.9 & 68.9 \\
\hline $60-70 \%$ & 4 & 6.6 & 75.4 \\
\hline $70 \%$ & 15 & 24.6 & 100.0 \\
\hline Total & $\mathbf{6 1}$ & $\mathbf{1 0 0 . 0}$ & \\
\hline
\end{tabular}

Source: Own elaboration

Table 2: Distribution of firms according to their export propensity.

\section{Results and Discussion}

Before revealing the results of the investigation, it must first be noted that compared to the territorial distribution of enterprises, the majority belong to the Hérault department with $62.3 \%$ of the total, followed by $14.8 \%$, confirming them as the most active and dynamic areas of the region.

\section{Descriptive analysis of SME exporters}

We start the explanatory results of empirical research with analysis from a variety of variables that allow us to make an initial descriptive approach on the main aspects that characterize the group studied. First, from a sectorial perspective, in Table 1 we can verify that almost $64 \%$ of all companies have a link with two sectors of the Languedoc-Roussillon region with higher tradition and international presence in namely agribusiness and wholesale trade. It takes more to highlight that 30 businesses (49.2\% of total) produce and market products, 16 have an exclusively commercial character and the other 15 belong to the service sector and research and development (Table 1).

As for the size of the company, it was observed that the number of staff $61.7 \%$ of companies is between 1 and 10 employees for the operation of all of their activities. Also, it may be noted that the turnover of $41 \%$ of these SMEs is less than 1 million.

As for variables directly related to the international aspects, it stands in the first place and as reflected in Table 2, the majority of companies intend to export more than $20 \%$ of their production, which indicates that they have a presence International consolidated enough (Table 2).

Secondly, and from a geographical point of view, more than $86 \%$ of companies consider the 15 countries of the European Union as an area of strategic interest to market their products, followed by North America and Asia-Pacific. No doubt a choice that comes from the intention that these SMEs give the purchasing power and the level of demand for French products in these countries, but also because of the fact that wine products are the most exported by the region LanguedocRoussillon, which explains $73.8 \%$ of the SMEs surveyed do not consider North Africa and the Middle East as target markets, the opposite of Asia; especially taking into account the considerable increase in the demand of French wine in China and Japan (Figure 1).

Regarding the main obstacles faced by companies in their internationalization process (Figure 2), it was observed that as the first impediment complexity of regulations and administrative standards, followed by the lack of profitability of operations due to costs and the e overstated value of the euro. It should not be forgotten that the sector with the largest presence in foreign markets is the food industry, which implies the need for a series of certifications for marketing their products, such as phytosanitary certificates or other specific each country. In return, the remaining obstacles were not considered weight for export impediments, indicating the veterance of SMEs abroad (Figure 2).

In relation to the factors that influence the decision to undertake an international activity, we first need to distinguish the increase in turnover with $88.4 \%$ of affirmative responses, followed by the level of demand in the target countries/markets with $78.7 \%$ and finally the risk diversification $(73.8 \%)$. Regarding human resources or organizational structure, it was found that $55.7 \%$ of companies do not have an export department as such (exports are carried out by commercial that normally handle domestic sales), possibly because of its cost or due to the fact that companies are rather TPE incorporate multiactive workforce to develop the various daily tasks.

To support agencies for export, it was observed that $9.8 \%$ of companies know no external promotion of existing institutions

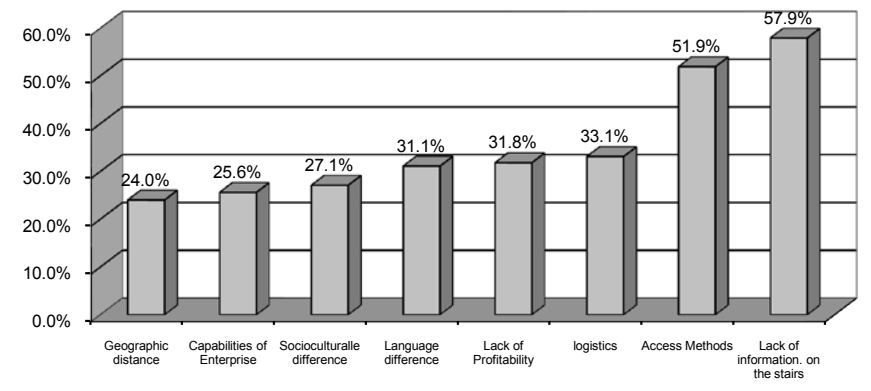

Source: own elaboration

Figure 2: Barriers to access to international markets. 

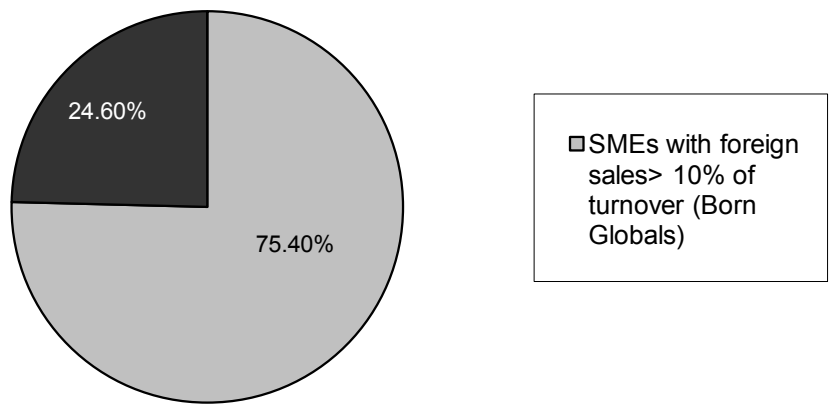

Figure 3: Percentage of SMEs "born globals".

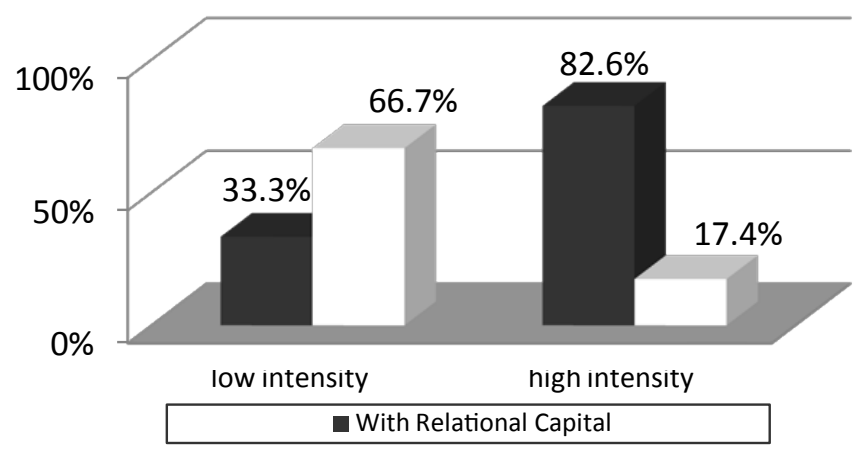

Figure 4: Intensity according exporterrelational capital ( $n=61$ companies).

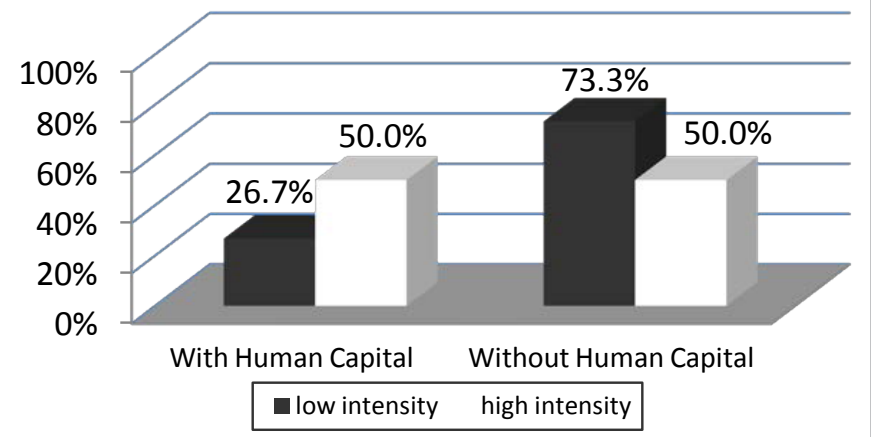

Figure 5: Intensity according exporterhuman capital ( $\mathrm{n}=61$ companies).

in Languedoc-Roussillon, while $26.2 \%$ had never attended any of the various programs offered. The most known organisms remain Ubifrance and Sud de France Export, not only for their excellent reputation for the quality of their services, but also to their presence in the majority of countries that may be of interest to the French company in general.

Support programs for the internationalization most requested by companies of the region are those relating to the participation in international fairs and exhibitions $(73.8 \%)$, followed by programs that promote inter-contractors meetings, then in a last FASEP we find the system of guarantees and FORMATEX specialized training programs.

The results of the survey, only $24.6 \%$ of companies prefer to start their export activities gradually, while the remaining $75.4 \%$ perform a rather entrepreneurial management internationalization without giving any priority to geographical proximity, because according to the survey client countries exporting companies of Languedoc-Roussillon are those of the European Union, North America and Asian countries
Thirdly, therefore, we can say that their internationalization process is totally opposed Theoretical Model in Uppsala, selection of European countries is because they are considered an extension of the local or national market. Regarding socio-cultural differences, they seem not to influence the decision to export of these SMEs, which leads us to deduce once again that it is these behaviors that characterize the companies referred Born Globals.

It may seem contradictory us that the Bron Globals companies represent $75.4 \%$ of the sample firms, while only $44.3 \%$ of the total have export service in their organizational structure, the explanation comments provided by the companies is that they realize all of their activity abroad, that should not be interpreted as a lack of specialized human capital, but just the opposite, the knowledge and the experiences are part of the intangible capital of SMEs, which integrate their structure and consolidate as a know-how and expertise necessary for the operation of the company's business (Table 3).

In conclusion, it is clear that exporting SMEs in the LanguedocRoussillon region is mainly characterized to have an average technological level, have a high level of relational capital and having a predominantly specialized in international trade workforce; Add to this that they attach no importance to the geographical distance and sociocultural differences when deciding their entry into foreign markets, their decisions are often motivated by rational reasoning which aims to increase turnover of the company and to diversify risk, and will be guided by the level of external demand in target countries and their purchasing power.

\section{Econometric Study}

In this part we will try to verify the role of certain structural factors in the process of SME internationalization Born Globals Languedocroussillonnaises.

\begin{tabular}{|c|c|c|c|c|c|c|}
\hline \multirow{2}{*}{ Factors } & \multicolumn{2}{|c|}{$\begin{array}{c}\text { With Export } \\
\text { Department }\end{array}$} & \multicolumn{2}{|c|}{$\begin{array}{c}\text { Without Export } \\
\text { Service }\end{array}$} & \multicolumn{2}{|c|}{ Total } \\
\cline { 2 - 7 } & $\mathbf{n}$ & $\%$ & $\mathbf{n}$ & $\%$ & $\mathbf{n}$ & $\%$ \\
\hline Export Service Internal: & 27 & 44.3 & 34 & 55.7 & 61 & 100 \\
\hline
\end{tabular}

Source: Own elaboration

Table 3: Distribution of SMEs with internal trade services.

\begin{tabular}{|c|c|c|c|c|c|c|}
\hline \multirow{2}{*}{ Factors } & \multicolumn{5}{|c|}{ Export intensity } \\
\cline { 2 - 8 } & \multicolumn{2}{|c|}{ Low } & \multicolumn{2}{|c|}{ Forte } & \multicolumn{2}{c|}{ Total } \\
\hline Influence of Psychic Distance: & $\mathbf{n}$ & $\mathbf{\%}$ & $\mathbf{n}$ & $\mathbf{\%}$ & $\mathbf{n}$ & $\%$ \\
\hline Considerable influence & 2 & 13.3 & 6 & 13.0 & 8 & 13.1 \\
\hline Uninfluential & 13 & 86.7 & 40 & 87.0 & 53 & 86.9 \\
\hline Total & $\mathbf{1 5}$ & $\mathbf{1 0 0 . 0}$ & $\mathbf{4 6}$ & $\mathbf{1 0 0 . 0}$ & $\mathbf{6 1}$ & $\mathbf{1 0 0 . 0}$ \\
\hline
\end{tabular}

$p=0.977$ Not Significant

Source: Own elaboration

Table 4: Socio-cultural differences according intensity export.

\begin{tabular}{|c|c|c|c|c|c|c|}
\hline \multirow{2}{*}{ Factors } & \multicolumn{6}{|c|}{ Export intensity } \\
\cline { 2 - 8 } & \multicolumn{2}{|c|}{ Low } & \multicolumn{2}{c|}{ Forte } & \multicolumn{2}{c|}{ Total } \\
\hline Influence of Geographic Distance: & $\mathbf{n}$ & $\mathbf{\%}$ & $\mathbf{n}$ & $\mathbf{\%}$ & $\mathbf{n}$ & $\mathbf{\%}$ \\
\hline Considerable influence & 2 & 13.3 & 15 & 32.6 & 17 & 27.9 \\
\hline Uninfluential & 13 & 86.7 & 31 & 67.4 & 44 & 72.1 \\
\hline Total & $\mathbf{1 5}$ & $\mathbf{1 0 0 . 0}$ & $\mathbf{4 6}$ & $\mathbf{1 0 0 . 0}$ & $\mathbf{6 1}$ & $\mathbf{1 0 0 . 0}$ \\
\hline
\end{tabular}

$p=0.148$ Not Significant

Source: Own elaboration

Table 5: Geographic distance according export intensity. 


\begin{tabular}{|c|c|c|c|c|c|c|}
\hline \multirow{2}{*}{ Factors } & \multicolumn{5}{|c|}{ Export intensity } \\
\cline { 2 - 7 } & \multicolumn{3}{|c|}{ Low } & \multicolumn{2}{c|}{ Forte } & \multicolumn{2}{c|}{ Total } \\
\hline Influence of Relational Capital: & $\mathbf{n}$ & $\mathbf{\%}$ & $\mathbf{n}$ & $\%$ & $\mathbf{n}$ & $\%$ \\
\hline Considerable influence & 5 & 33.3 & 38 & 82.6 & 43 & 70.5 \\
\hline Uninfluential & 10 & 66.7 & 8 & 17.4 & 18 & 29.5 \\
\hline Total & 15 & $\mathbf{1 0 0 . 0}$ & $\mathbf{4 6}$ & $\mathbf{1 0 0 . 0}$ & $\mathbf{6 1}$ & $\mathbf{1 0 0 . 0}$ \\
\hline $\mathbf{p}<\mathbf{0 . 0 1}$ Significant & \multicolumn{4}{|c|}{} \\
\hline
\end{tabular}

Source: Own elaboration

Table 6: Relational capital intensity according export.

\begin{tabular}{|l|c|c|c|c|c|}
\hline Factors & $\boldsymbol{\beta}$ & $\mathbf{p}$ & GOLD & \multicolumn{2}{|c|}{$95 \%$} \\
\hline Specialized Human Capital: & & & & & \\
\hline With Human Capital & 1.674 & 0.010 & 5.34 & 1.50 & 19.01 \\
\hline Without Human Capital & & & 1.00 & & \\
\hline Relational Capital: & & & & & \\
\hline With Relational Capital & 1.813 & 0.018 & 6.13 & 1.36 & 27.68 \\
\hline $\begin{array}{l}\text { Without Relational Capital } \\
\text { Technological level of the }\end{array}$ & & & 1.00 & & \\
\hline Company/Product: & & & & & \\
\hline Advanced & 1.760 & 0064 & 5.81 & 0.90 & 37.51 \\
\hline Average & 1.476 & 0099 & 4.38 & 0.76 & 25.24 \\
\hline Constant: & 3191 & 0.003 & & & \\
\hline
\end{tabular}

Source: Own elaboration

Table 7: Factors associated with export intensity.

\begin{tabular}{|c|c|c|c|c|}
\hline \multirow{2}{*}{ Factors } & \multicolumn{4}{|c|}{ Export intensity } \\
\cline { 2 - 5 } & \multicolumn{2}{|c|}{$\begin{array}{c}\text { With Human } \\
\text { Capital }\end{array}$} & \multicolumn{2}{c|}{$\begin{array}{c}\text { Without Human } \\
\text { Capital }\end{array}$} \\
\hline Relational Capital: & $\mathbf{n}$ & $\%$ & $\mathbf{n}$ & $\%$ \\
\hline With Relational Capital & 22 & 81.5 & 21 & 61.8 \\
\hline Without Relational Capital & 5 & 18.5 & 13 & 38.2 \\
\hline Total & $\mathbf{2 7}$ & $\mathbf{1 0 0 . 0}$ & $\mathbf{3 4}$ & $\mathbf{1 0 0 . 0}$ \\
\hline
\end{tabular}

Significant $\mathrm{p}=0.09410 \%$

\section{Source: Own elaboration}

Table 8: Contingency table Specialized human capital/capital relationship.

Zahra et al. [16], and Knight [5] Born Globals defined as all companies which achieved net sales outside higher to $25 \%$ in the first 6 years after their creation. Also, Bals et al. [17] established an exporting company can be classified as Born Global when it's sales in international markets, reach or exceed the $10 \%$ threshold of total turnover case during the first three years after its creation. We decided to use the second criterion.

Using data obtained from surveys and applying the criteria mentioned previously, it was observed that 61 SMEs surveyed, $54.3 \%$ can be classified as Born Globals, indicating the strong international orientation of firms the region (Figure 3).

To perform this analysis we will use the database we created, it will allow us to know the factors that have a direct influence on the export intensity of the companies identified as Born Globals i.e, saturation or degree of rivalry in the region, the level of external demand in target markets, socio-cultural and geographical distance between the company and foreign markets, relational capital of the company measured by participation in various events for the international promotion, human capital using structural data which is that of the existence of a specialized export department within the company, the technological level, geographic location, the business sector and the company size. It is using these ten variables to make an econometric model to determine those that have a significant influence on the exporting intensity and behavior of the exporting Languedoc-Roussillon SMEs.

\section{Definition of variables}

\section{Dependent variable:}

Export intensity: We will adopt the most used definition in the literature that relates to the dependence of the company from sales abroad. According to the work of Bals et al. [17] based on those of Lianxi et al. [18] and Moen and Servais [19] This variable is defined as the percentage of international sales compared to the turnover.

It took split this variable into two categories, defined as a dummy (silent dummy) having the values 0 and 1 :

- SMEs with total sales outside less than or equal to $10 \%$ of turnover, taking the value 0

- SMEs with total sales outside the upper $10 \%$ of the turnover, taking the value 1

\section{Independent variables:}

Degree of rivalry or saturation of the domestic market: This variable is rooted in earlier studies, conducted by Hackett [20] and by Aydin et al. [21] and has determined that the saturation of the domestic market is a factor affects the internationalization of companies. Also, Ben et al. [22] conducted research based investigating the case of franchises; they were able to conclude that the decrease in growth of domestic markets or saturation, is a factor that leads companies to seek other markets beyond their borders.

H1: The saturation or degree of rivalry in the national/local market, has a positive influence on the intensity of exporting companies.

Level of external demand in target countries-markets: The level of external demand appears as a key factor in the growth of exports, while considering the close relationship between the real income of target markets and relative prices of goods to be exported. Empirically and a longitudinally, it was demonstrated that the level of global demand is an important determinant of exports, reference is made to the research work that treated the determinants of export performance of engineering products of India [23] as the work of Zesahn et al. [24] who studied the role of demand in international trade of Pakistan and those of Alexis and Thomas [25] who treated external demand as a determining variable export growth, creating opportunities and technical progress of developing countries.

$\mathrm{H} 2$ : The external demand level of the target country markets has a positive effect on the exporting intensity.

Sociocultural distance: This variable represents mainly the cultural, linguistic and educational differences between the region and target country markets, using the concepts developed by the Uppsala Model $[1,2]$ and it is a variable that was theoretically considered by companies as e a risk factor for International Operations and uncertainty related to forms to interact with potential customers.

H3: The existence of socio-cultural distances (psychic) between SMEs and foreign countries markets, has no effect on the exporting intensity.

Geographic distances: With characteristics similar to the previous one, this variable refers to the geographical gap between business and client countries. This is a variable that has been defined in the Theory Uppsala, described as an important factor in international trade activities, mainly for new businesses [1,2]. 
H4: The geographical distance between SMEs and target-country markets, has no influence on the exporting intensity.

Relational capital: The influence of relational capital especially between creating new businesses, is determined by any relationship with the environment that adds value to the organization. The role of the entrepreneur is significant extremely when establishing and developing external relationships of the company, often using their personal networks [26] having social networks of special importance, social since capital is an importance source of legitimacy and knowledge required for success internationally [27] whether for Born Globals $[4,16]$ or to companies that adopt a gradual process towards internationalization. Several research studies have claimed that companies that are share of a social network reliable pour augmenter their competitive advantage, and that the strategic groups generally improve corporate performance, particularly for the establishment of new SMEs [28].

H5: The relationship capital exporting SMEs, has a positive effect on the intensity Exporting.

Human capital: From a theoretical point of view of, there are many studies-have that examined the impact of specialized staff (human capital) having experience in international trade, the internationalization of a business process [29-31] being white the most significant research those made by authors decision $[7,32,33]$ to confirm the positive role of staff specialized in the international expansion of companies.

H6: The human capital has a positive influence on the export intensity of the companies

The technological level: The technological factor is regarded significant element for business year we competitiveness international markets [34,35]. Benjamin et al. [7] demonstrated that differences in competitive advantages entre wide and small businesses in foreign markets fell, and hold a competitive advantage internationally depends increasingly specific business assets [36,37]. So we can deduce the competitive international calls for more efficiency and effectiveness in the management of innovation processes, research and development that so companies can guarantee a successful presence in foreign markets [38].

H7: The technological level of the company has a positive influence export intensity.

The geographical rental of the company: This is a concept that is rooted in economic geography (spatial economy or economy of the territories), in fact the position of the company in terms of territoriality affects export intensity. At the theoretical level, a recent research work conducted by Stephanie et al. [39] have-been examined and determined empirically the role of geography in the international development of businesses Born Globals. The general feeling from the study emerges that is that from an ecological point of view of local natural resources are indeed a significant factor in companies' internationalization process, confirming the results of numerous studies that-have tried to study the impact of the geographical location of the company is able to create and sustain competitive advantage in an era of economic globalization [39-44].

Also, industrial groupings (clusters)-have a catalytic role in the internationalization process, local and regional business through networks that allow players to develop interactions [44], and find an importance source of information, skills, knowledge of markets and opportunities to the international business [45].
H8: The location of the exporting company influences export intensity.

The company's business sector: The areas of greatest international success are characterized for companies with an innovative and proactive organizational culture [46]. In this context of globalization and interdependence, the innovation is the Ability of enterprises and economic Sectors in general to create new ideas, Introduce new products and services meet the requirements of target markets and their ability to find creative solutions to the challenges $[47,48]$.

Among the factoring than the literature suggests as potentially significant $\mathrm{s}$ for the international development of companies, there are sectorial factor in terms of competitiveness and the ability to provide high value-added products, being white the technological level of a specific sector a key element $[48,49]$, since companies belong to that year economic sector with high technological level, are competitiveness to-have a strong export intensity, and internationalization as a who perceive necessary strategic option [50].

H9: The activity sector of the company influences export intensity.

The size of the company: The question that often arises about a possible relationship between the export behavior of companies and their organizational size, says with certainty That large companies should be factoring of competitive advantage, related to their size that would allow their activities export international expansion or tohave more success [51-54]. This positive sign of supposed relationship entre firm size and export activities is due to the principle that large companies-have the advantage of achieving wider and more intense equity trading thus, it is regarded that export companies are expected pour augmenter gradually as their size. In addition, as the company size increases, the dirty that it makes abroad increase should more than proportionately [55,56].

H10: The size of the organizational structure of the company, it has year impact export intensity.

\section{Econometric analysis}

For the econometric analysis of the Languedoc-Roussillon, we will logistic regression analysis was driving to identify various significant factoring that determines the strong export intensity of SMEs in the area. Of the ten variables that can affect the process of internationalization and export intensity of SMEs LanguedocRoussillon, we approbation three significant factoring that are essential for their export performance:

The saturation of the domestic market appears without any association with the export intensity ( $>0.05)$, due to what categories of the variable are equitably distributed both entre low intensity as those companies with high export intensity. Thus, the category "no impact" represents $40.0 \%$ of the total, a $5.2 \%$ increase among low-intensive companies.

They reviews the other hand, there was no significant relationship entre export intensity of the area and the impact of the level of external demand ( $p>0.05)$. However, there is a tendency than the low intensity is associated with low level of impact of the variable "external demand" and vice versa (Table 4).

Compared to the socio-cultural distance, no combination is found entre this variable and the export intensity $(p>0.05)$ due to the distribution of the variable. The frequency of responses that claim to-have no impact on their internationalization process was almost 
equal among low export-intensive companies (86.7\%) than intensive (87.0\%) (Table 5).

The four variables that were previously analyzed won't be regarded logistic regression model for the, since none of them: has a significant association with the response variable (Table 6).

Regarding relational capital, there is a significant association with the export intensity $(\mathrm{p}<0.01)$, as $82.6 \%$ of companies intensive-have in even entre those with low intensity we can see that difference is as significant as crucial to the internationalization of enterprises (49.3\%) (Figure 4).

They review the other hand companies-have that specialized human capital is more common among the high export-intensive businesses (50\%) against the $26.7 \%$ among those with low intensity (Figure 5).

In terms of technological product level, Chi-square test $\mathrm{p}=0.048$ Indicated which confirms the combination of this factor with the exporting intensity. Between enterprises was observed with high export intensity $42.2 \%$ have an advanced level of technology while in the low-intensity group this percentage is $33.3 \%$. It reviews the other hand, $22.2 \%$ of companies with artisan production system-have strong export intensity.

The variable "industry" Indicated a weak relationship entre export intensity and industry $(\mathrm{p}=0.607)$, being white sectors that most associate associated with strong export intensity and agribusiness chemical industry, wholesale trade and recreation, with a difference of $10.2 \%$ for the food industry and the chemical industry $(43.5 \%=$ high intensity, low intensity $=33.3 \%$ ) and $11.6 \%$ for industry research and development and manufacture of machinery $(21.7 \%=$ high intensity, low intensity $=33.3 \%$ ), profit they remain Insufficient differences to be reliable to include this variable in the logistic model.

Furthermore, there is no relationship entre firm size and export intensity of SMEs in the area. This fully justified the level of significance $\mathrm{p}=0.290$ Observed chi-square test the companies were grouped according to the number of their workforce. ( $\leq 10$ employed small businesses and medium enterprises employed $\geq 10$ ).

According to the value observed significance in the Chi-square test, the most significant explanatory variables to predict the intensity of export Languedoc-Roussillon SMEs are: relational capital, the technological level of the company/product and human capital (Table $7)$.

Companies with a specialized human capital were 5 times more likely to-have a strong export intensity (or=5.34) compared to companies without this factor, it is significant to notes than the total of SMEs that factor, $81.5 \%$ also HAD Some relationship capital, while Specialized Among Those without human capital, less than half (38.2\%) were not factoring relational, a very significant difference $(p=0.094$ Chi-square with the test). However, two factoring are interrelations with a $90 \%$ confidence interval (Table 8 ).

Candidate variables for the logistic regression model, we get the following equation:

$\log (p /(1-p))=-3,191+1,674 \quad($ CapH $)+1.813 \quad($ GARP $) \quad 1.760$ (TecnAv)+1.476 (TecnIt)

Gold:

CapH: Takes 1 when the value of the company has the specialized human capital, and 0 in the opposite case.
GARP: Takes the value of 1 when the company has the relational capital, and 0 in the opposite case.

TecnAv and TecnIt: Take the value of 1 and 0 when the level of technology is advanced, 0 and 1 for intermediate levels 0 and 0 if the level is basic technological craft gold.

\section{Conclusions}

The present work tried to achieve achievement and Increase our understanding of the internationalization process followed us $\mathrm{s}$ by SMEs, taking into account different factoring that influences their involvement in international trade activities. Although currently the Uppsala model and approach of Born Globals provide us the explanation of described the processes, and it seems that having operate some kind of factoring is what really olefins corporate commitment abroad.

From the descriptive analysis the carried out it was observed that a significant number of low-intensity export SMEs-have neither the human capital necessary relational gold for an adequate level of competitive in international markets. From reviews another perspective, the econometric study was able to determine that some structural elements EMS Born Globals are essential to-have intense year presence in foreign markets and the therefore in Greater commitment on their export activities. However, we can confirm that companies have an international position strong are those with a set of structural factoring, human and relational.

The main difference entre les low export intensity SMEs are the Born Globals is the importance to the grant they socio-cultural and geographical distance in terms of perception of risk, it has-been demonstrated that thesis are factoring that negatively international business can influence.

\section{Proposals and Recommendations}

One of the main needs of exporting SMEs in the area a concerns their need to strengthen their strategic positioning. The introduction of some improvements in their organizational aspects Will enable the conversion of some or even productive-technological capabilities to accomplish achieve better results in foreign markets, and promote the adoption of a greater level of compromised through innovation and improving their technological base. It is the therefore appropriate to continue to invest in the establishment and development of assets in the forefront of innovation to supporting the internationalization of the company.

Internally, it seems appropriate to promote the specialization of tasks related to export grouped in departments or divisions with some autonomy. The presence of such organizational units implies has international engagement Greater. SMEs should be provided with a potential of more specialized and trained especially in foreign trade, with functions that go beyond the simple contact with foreign customers or to fulfill specific paperwork, customs formalities (etc.), goal also should be more Involved in the development of the international strategy of the company and the realization of market research.

Externally, and the therefore closely linked to the mechanisms of production and international distribution should be striving for greater control and less vulnerable position of the company internationally it markets through the establishment of exclusive distribution networks, as well as greater use of innovative forms of inter-firm cooperation as franchises, joined ventures (joint ventures) and business and technological agreements. Some of these organizational formulas allow deepening the relationship with foreign distributors, which seems 
especially suitable and necessary for SMEs, qui usually do not-have the resources requested by international the activity.

However, it remains significant logistical and supporting infrastructure of various institutions and public agencies (Ministries, Urbifrance, Sud de France Export, the Chambers of Commerce, industry associations, etc.) that can act at several levels: by training, promoting the learning of other languages, prepaid specialists in international trade and promoting access to economic aid. For information diversifying and again more services free by the specialized agencies and sales offices outside network, facilitating access to databases, conducting seminars is external marketing and new opportunities investment by geographical area, as well as promotional work by developing formulas that facilitate the integration of businesses into international trade networks (trading companies, export associations, sectoral associations of exporters, etc.) not to mention the financial and fiscal aspects with the removal of international dual taxation, improving the tax treatment received by direct investment, subsidy insurance cover s that the business risk; and in general a more active participation of banks in the SME internationalization process.

\section{References}

1. Wiedersheim F, Jan-Paul J (1975) The internationalization of the firm - Four Swedish cases. Journal of Management Studies 12: 305-323.

2. Johanson J, Jan-Erik V (1977) The internationalization process of the firm - A model of knowledge development and Increasing foreign market commitments. Journal of International Business Studies 8: 23-32.

3. Bent P, Pedersen T (1998) Explaining gradually increasing resource commitment to a foreign market. International Business Review 7: 483-501.

4. Oviatt BM, McDougall PP (1995) Global start-ups: Entrepreneurs worldwide internship was. The Academy of Management Executive 9: 30-43.

5. Knight GA, Cavusgil ST (1996) The born global firm: A challenge to traditional internationalization theory. Advances in International Marketing 8: 11-26.

6. Oviatt BM, McDougall PP (2005) Defining international entrepreneurship and modeling the speed of internationalization. Entrepreneurship Theory and Practice 29: 537-554

7. Oviatt MB, McDougall PP (2005) The internationalization of entrepreneurship. Journal of International Business Studies 36: 2-8.

8. Oviatt MB, McDougall PP (2005) Toward a Theory of International New Ventures. Journal of International Business Studies 36: 29-41.

9. Dunning JH (1995) Reappraising the eclectic paradigm in an age of alliance capitalism. Journal of International Business Studies 26: 461-491.

10. John Cantwell (1995) The globalization of technology: What remains of the product cycle model? Cambridge Journal of Economics 19: 155-174.

11. Calof Jonathan $L$ (1993) The impact of size is internationalization. Journal of Small Business Management 31: 60-69.

12. Calof Jonathan $L$ (1993) The fashion choice and change decision process and Its Impact international performance is. International Business Review 2: 97-120.

13. Vaupel JW, Curhan JP (1970) The making of multinational enterprise. The International Executive 12.

14. Vaupel JW, Curhan JP (1974) The World's Multinational Enterprises. The International Executive 16.

15. Jan-Erik V, Johanson J (2003) Business Relationship Learning and the Commitment in the Internationalization Process. Journal of International Entrepreneurship 1: 83-101.

16. Zahra SA, Ireland RD, Hitt MA (2000) International expansion by new venture firms: International diversity, mode of market entry, technological learning, and performance. Academy of Management Journal 43: 925-950.

17. Bals L, Heather B, Evi H (2008) What is a" Born Global firm?" Academy of International Business Annual Meeting, Chicago, USA.

18. Zhou L, Wei-ping W, Luo X (2007) Internationalization and the performance of born-global SMEs: the Mediating Role of social networks. Journal of International Business Studies 38: 673-690.

19. Servais P, Oystein M (2002) Born Global gold Gradual Global? Examining the Export Behavior of Small and Medium.

20. Donald WH (1976) The international expansion of US Franchise systems: Status and Strategies. Journal of International Business Studies 7: 65-75.

21. Aydin N, Kacker M (1990) International outlook for US-based franchisors. International Marketing Review 7: 43-53.

22. Ben KL, Ackerman DJ, Bush DE, Robert TJ (1994) Determinants of internationalization of franchise operations by US franshisors. International Marketing Review 11: 56-68.

23. Goldar B (1989) Determinants of India's export performance in engineering products, 1960-79. The Developing Economics 26: 3-18.

24. Zeshan A, Mohsin Hasnain A (2003) The supply and demand for exports of Pakistan: The polynomial distributed lag model (PDL) approach. The Pakistan Development Review 42: 961-972.

25. Alexis H, Thomas Z (2008) Export demand elasticities as determinants of growth: Estimates for Mauritius. United Nations University-Maastricht Economic and social Research and training center on Innovation and Technology (UNUMERIT).

26. Mary H (2006) Developing social capital to accomplish achieves superior internationalization: A conceptual model. Journal of International Entrepreneurship 4: 99-112.

27. Arenius $P(2005)$ The psychic distance postulate revised: from selection to speed market penetration. Journal of International Entrepreneurship 3: 115-131.

28. Angelmar $R$ (1984) Product acceptance by middlemen in export channels. Journal of Business Research 12: 227-240.

29. Reuber RA, Fischer E (1997) The influence of the management team's international experience on the internationalization behaviors of SMES. Journal of International Business Studies 28: 807-825.

30. Manigart S, Collewaert V, Wright M, Pruthi S, Lockett A, et al. (2007) Human capital and the internationalization of venture capital firms. International Entrepreneurship and Management Journal 3: 109-125.

31. Ruzzier M, Bostjan A, Robert DH, Maja K (2007) Human capital and SME internationalization: A structural equation modeling study. Canadian Journal of Administrative Sciences 24: 15-29.

32. Buckley PJ (1993) The role of management in internalization theory Management International Review 33: 197-207.

33. McDougall PP, Shane S, Oviatt BM (1994) Explaining the formation of International New Ventures: The limits of theories from international business research. Journal of Business Venturing 9: 469-487.

34. Porter ME (1985) Technology and competitive advantage. Journal of Business Strategy 5: 60-78.

35. Smith, Stephen C (1990) The competitive advantage of nations: Michael E. Porter, (Free Press, New York, 1990) pp. xx + 855

36. Barney J (1991) Firmresources and sustained competitive advantage. Journal of Management 17: 99-120.

37. Prahalad CK, HamelG (1990) The core competence of thecorporation. Harvard Business Review 68: 79-91.

38. Necmi K, Martin L (1998) Internationalization of small and medium-sized technology-based firms: An exploratory study. Journal of Small Business Management 36: 44-59.

39. Fernhaber S, Gilbert B, McDougall P (2008) International Entrepreneurship and geographic location: An empirical examination of new venture internationalization. Journal of International Business Studies 39: 267-290.

40. Maskell P, Malmberg A (1999) The competitiveness offirms and regions: 'Ubiquitification' and the importance of localized learning. European Urban and Regional Studies 6: 9-25.

41. Olivier T (2003) Petitesse companies magnification and proximity effects French Review of Management 3: 119-138.

42. Michael EP (2000) Location, competition, and economic development: Loca 
clusters in a global economy. Economic Development Quarterly 14: 15-34.

43. Niosi J, Netherlands TG (2001) The Competencies of Regions - Canada's clusters in biotechnology. Small Business Economics 17: 31-42.

44. Bresnahan T, Gambardella A, Saxenian A (2001) 'Old Economy' inputs for 'new economy' outcomes: Cluster formation in the new Silicon Valleys. Industrial and Corporate Change 10: 835-860.

45. Saxenian A (1990) Regional networks and the resurgence of Silicon Valley. California Management Review 33: 89-112.

46. Nicole CE, Hugh JM (1995) Growing the entrepreneurial firm: Networking for international market development. European Journal of Marketing 29: 49-61.

47. Dimitratos P,Plakoyiannaki E (2003)Theoretical foundations of an international entrepreneurial culture. Journal of International Entrepreneurship 1: 187-215.

48. Frederic LR, Torres $\mathrm{O}$ (2001) The role of innovation in competitive strategies of international SMEs" Innovations 1: 43-60.

49. Gael G, PeyrouxC, Olivier T (2007) Degree of internationalization and innovation practices: the case of Polish SMEs'. Thirteenth International Conference PGV network, Lisbon.
50. Thorelli HB (1986) Networks: Between markets and hierarchies. Strategic Management. Journal 7: 37-51.

51. Crick D, Spence M (2005) The internationalization of 'high performing' UK high-tech SMEs: A study of planned and unplanned strategies. International Business Review 14: 167-185.

52. Paul WB, Munro M (1986) The export performance of small and medium-sized Canadian manufacturers. Canadian Journal of Administrative Sciences 3: 29-40.

53. Kenneth GH (1987) Key Success Factors for Small / Medium Sized Canadian Manufacturers Doing Business in the United States. Business Quarterly 51 67-73.

54. Marchesnay M (1991) The SMEs specific management. Rural Economy 206: 11-17.

55. Bonaccorsi A (1992) On the relationship between firm size and export intensity. Journal of International Business Studies 23: 605-635.

56. Jonathan CL (1994) The relationship between firm size and export behavior revisited. Journal of International Business Studies 25: 367-387. 